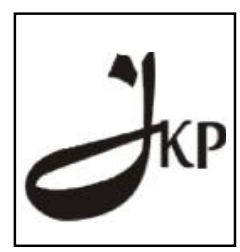

Jurnal Konseling dan Pendidikan

ISSN Cetak: 2337-6740 - ISSN Online: 2337-6880

http://jurnal.konselingindonesia.com

Volume 1 Nomor 1, Februari 2013, HIm 58-66

\title{
Penerapan Microskills dalam Domain Multicultural
}

\author{
Happy Karlina Marjo ${ }^{1 *}$ \\ ${ }^{1}$ Universitas Negeri Jakarta
}

\begin{abstract}
Konselor multikultural menggunakan microskills yang bertujuan untuk memodifikasi interaksi konselor dalam membuat perbedaan yang signifikan pada kehidupan konseli dengan: (1) mengidentifikasi faktor-faktor dari respon nonverbal untuk diri konselor sendiri dan konseli, (2) memahami dasar intervieu microskills dalam proses menerima (attending), mendengarkan (listening), dan mempengaruhi (influencing), serta dampak potensial pada konseli untuk berubah, (3) mencatat fokus microskills, dan perhatian secara selektif yang merupakan dasar untuk masalah keluarga dan konseling multikultural, (4) mengetahui bagaimana dan kapan menggunakan konfrontasi microskill, dan (5) mengetahui keterampilan intervieu sebagai acuan frame multikultural. Sedangkan domain kompetensi konseling multikultural untuk pendidikan dan praktek, antara lain: (1) Counselor Awareness of Own Cultural Values and Biases), (2) Counselor Awareness of Client'Worldview), dan (3) Culturally Appropriate Intervention Strategies.
\end{abstract}

Keyword: Microskills, Domain Multikultural, dan Konselor Multikultural.

Copyright (C) 2013 IICE - Multikarya Kons - All Rights Reserved

Indonesian Institute for Counseling and Education (IICE) Multikarya Kons

\section{PENDAHULUAN}

Konseling multikultural mengubah cara pandang kita memahami hubungan konseling. Menurut Pedersen, Draguns, Lonner, \& Trimble (2002) konseling multikultural mengubah banyak paradigma yang telah mengendalikan profesi konselor selama 50 tahun terakhir. Senada dengan hal tersebut, menurut Essandoh (1996) memunculkan kemungkinan bahwa konseling multikultural mewakili sebuah paradigma baru dalam profesi konseling-sebuah "tekanan keempat".

Menurut Locke \& Faubert (2003) hal ini sebenarnya mungkin tekanan keempat yang akan menjadi instrumen dalam mengubah profesi pada milenium mendatang. Konsep konseling multikultural telah berubah dari tahun ke tahun dan berlanjut masih berubah terus menerus. Hal ini senada dengan pernyataan Patterson (1996) bahwa penekanan yang berlebihan sekarang ini

\footnotetext{
Telp dan/atau Alamat Email Koresponden : 'Email: happykarlina@ymail.com
} 
Jurnal Konseling dan Pendidikan

pada perbedaan budaya dan konseling khusus budaya membawa pada sebuah fokus teknik tertentu, dengan konselor yang menjadi seorang yang dapat merubah gaya, teknik, dan metode untuk memenuhi karakteristik yang diperkirakan dari konseli yang mempunyai budaya yang berbeda.

Konselor multikutural membantu konseli dalam menangani permasalahan-permasalahan dalam mengidentifikasi faktor-faktor dari respon nonverbal untuk diri konselor sendiri dan konseli; memahami dasar intervieu mikroskills dalam proses menerima (attending), mendengarkan (listening), dan mempengaruhi (influencing), serta dampak potensial pada konseli untuk berubah; mencatat fokus mikroskills, dan perhatian secara selektif yang merupakan dasar untuk permasalahan masalah keluarga, dan konseling multikultural; konselor menggunakan konfrontasi mikroskill; dan mengetahui keterampilan intervieu sebagai acuan frame multikultural.

Microcounseling selama bertahun-tahun terus-menerus menekankan fokus keseimbangan antara masalah pribadi dan kontekstual, terutama budaya dan lingkungan. Microcounseling (Ivey, 1971; Ivey \& Ivey 2003) menekankan pentingnya konsep fokus dalam intervieu. Intervieu mikroskills dalam proses konseling, antara lain: menerima (attending), mendengarkan (listening), dan mempengaruhi (influencing), serta dampak potensial pada konseli untuk berubah. Konselor berfokus pada konseli dan permasalahannya, sedangkan microcounseling yang diterapkan oleh konselor dalam membantu konseli dengan frame multikultural dalam mengembangkan pertanyaan konseli, biasanya diberikan secara individual yang berfokus pada masalah konseli dan tanggung jawabnya untuk perubahan konseli.

\section{PEMBAHASAN}

\section{Pendekatan Microskills}

Proses identifikasi dan seleksi keterampilan khusus pendekatan konseling yang disebut microskills. Menggunakan Pendekatan Microskills, kita dapat memecahkan interaksi kompleks dari intervieu konseling ke dimensi yang dapat dikelola dan dipelajari. Keterampilan dasar microskills termasuk menerima (attending), mendengarkan (listening), dan mempengaruhi (influencing). Keterampilan penting lainnya adalah fokus, perhatian selektif, dan konfrontasi. Yang mendasari dan membentuk keterampilan ini adalah faktor nonverbal untuk membawa konselor pada proses intervieu. Sebagai contoh, melalui bahasa tubuh dan ekspresi wajah, yang expresif dari sikap konselor terhadap konseli.

\section{Keterampilan Penerimaan Awal (Attending Skills)}

Bila Konselor melakukan intervieu atau memberikan nasihat kepada konseli, tampaknya jelas konselor harus melihat konseli dan mempertahankan kontak mata secara alami. Selanjutnya, tubuh konselor harus berkomunikasi. Hal ini pernah diyakini bahwa konseling hanya pekerjaan yang verbal, namun dengan munculnya rekaman video dan peningkatan penggunaan film pelatihan dalam intervieu tersebut, telah menjadi jelas bahwa komunikasi nonverbal adalah dasar dalam setiap intervieu atau konseling. Kontak mata dan bahasa tubuh merupakan aspek mendasar dari perilaku fisik pada penerimaan awal (attending behavior). Aspek mendasar lainnya dari attending behavior adalah nada suara.

Selain itu, jika Konselor ingin hadir untuk seseorang, konselor harus "mendengarkan". Mendengarkan, bagaimanapun, bukanlah suatu perilaku yang dapat diamati. Konselor sengaja tidak hanya untuk menjaga postur tubuh dan ekspresi wajah penuh perhatian, mereka juga tetap pada topik dengan konseli, dan jarang menyela atau tiba-tiba berubah topik pembicaraan (subjek). Kesalahan utama di awal proses penerimaan awal yang dilakukan konselor adalah mengubah topik diskusi, dan mengabaikan atau gagal untuk mendengarkan apa yang dikatakan konseli.

\section{- $\quad$ Attending dan Perbedaan Budaya}

Perilaku attending yang bervariasi dari budaya ke budaya, dan dari individu ke individu. Data jelas menunjukkan bahwa perbedaan individual di antara konseli mungkin sama pentingnya dengan polapola budaya. Ketika mempelajari pola budaya, jangan menganggap bahwa pola attending (atau influencing) yang tepat untuk setiap individu dari kelompok-kelompok budaya yang mungkin konselor intervieu. Pada pola attending nonverbal di budaya Eropa-Amerika Utara berbeda dengan pola budaya lain, seperti: kontak 
Jurnal Konseling dan Pendidikan

mata untuk pola Eropa-Amerika ketika mendengarkan seseorang, kontak mata langsung adalah tepat dan ketika berbicara, kontak mata biasanya kurang sering. Sedangkan budaya lainnya dari beberapa Amerika Afrika mungkin memiliki pola yang berlawanan dan menunjukkan kontak mata lebih ketika berbicara dan kurang saat mendengarkan.

\section{- Mencerminkan Perilaku Nonverbal}

Review sesi intervieu film dan video yang menarik pola komunikasi nonverbal. Dalam intervieu yang berhasil dan berjalan lancar, saling melengkapi gerakan komplementer atau gerakan simetri sering terjadi antara konselor dan konseli. Gerakan simetri antara konselor dan konseli diasumsikan secara tidak sadar memiliki postur fisik yang sama, kontak mata mereka biasanya langsung, dan tangan serta kaki dapat bergerak serentak seolah-olah mereka menari atau mengikuti script yang telah diprogram. Gerakan simetri dapat dicapai dengan sengaja yang diasumsikan bahwa postur dan gerak tubuh seperti "cermin" dari gerakan konseli. Hal ini mencerminkan perilaku nonverbal konselor sering dibawa ke pemahaman yang lebih dekat dan lebih lengkap dibandingkan konseli.

Konselor menjadi terampil dalam mengamati dan berlatih "mirroring", hal ini dapat menjadi alat yang berharga. Jika konselor melihat pola umum pada bahasa tubuh konseli, dan kemudian sengaja mengambil postur yang sama, konselor akan menemukan diri konselor lebih baik selaras dan harmonis dengan konseli. Dengan "mirroring", pemahaman baru dan komunikasi dapat berkembang. Alat ini tidak boleh digunakan untuk memanipulasi, tetapi untuk mengembangkan kesadaran yang lebih besar dan tingkat pengetahuan baru.

Keterampilan Mendengarkan (Listening Skills)

Keterampilan Attending dapat diorganisir menjadi suatu kerangka kerja yang koheren dan sistematis, yang disebut urutan dasar dari mendengarkan. Keterampilan attending dengan mengidentifikasi spesifik microskills dari mendengarkan: pertanyaan terbuka dan tertutup (open and closed questions), mendorong (encouraging), paraphrasing (parafrase), refleksi perasaan (reflection offeeling), dan kesimpulan (summarization). Semua keterampilan ini dimaksudkan untuk menyoroti cerita/sejarah konseli. Tujuan dari keterampilan mendengarkan adalah untuk menemukan bagaimana cerita konseli sendiri, dengan instruksi minimal dari konselor.

\section{Influensing Skills dan Strategi}

Keterampilan influencing dan fungsi konselor dirangkum dalam tabel 1.1 keterampilan influencing sangat kompleks, dan sering lebih efektif bila digunakan sedikit dalam hubunganya dengan kemampuan mendengarkan dengan cermat. Adapun pemaparan keterampilan influencing dalam tabel 1.1 menurut Ivey (1993), sebagai berikut:

\begin{tabular}{|c|c|c|}
\hline Keterampilan & Deskripsi & Fungsi dalam Intervieu \\
\hline Interpretasi & $\begin{array}{l}\text { Menyediakan kerangka kerja alternatif } \\
\text { di mana konseli dapat melihat situasi. } \\
\text { Bisa ditarik dari teori atau pengamatan } \\
\text { pribadinya. Interpretasi dapat dianggap } \\
\text { sebagai keterampilan inti untuk } \\
\text { mempengaruhi atau influencing skill. } \\
\text { Memberi tahu konseli apa yang harus } \\
\text { dilakukan. }\end{array}$ & $\begin{array}{l}\text { Upaya membantu konseli dengan } \\
\text { cara-cara baru untuk melihat } \\
\text { situasi. Interpretasi } \\
\text { memberikan konseli } \\
\text { persepsi yang jelas } \\
\text { alternatif pada "realitas." } \\
\text { ini mersepan } \\
\text { pendapat yang pada gilirannya } \\
\text { dapat menyebabkan perubahan }\end{array}$ \\
\hline
\end{tabular}




\begin{tabular}{|c|c|c|}
\hline & & $\begin{array}{l}\text { dalam pikiran, struktur atau } \\
\text { perilaku. }\end{array}$ \\
\hline Direktif & $\begin{array}{l}\text { Hal ini bisa menjadi saran sederhana } \\
\text { dinyatakan dalam bentuk perintah atau } \\
\text { bisa menjadi teknik canggih dari } \\
\text { sebuah teori tertentu. }\end{array}$ & $\begin{array}{l}\text { Jelas menunjukkan kepada konseli } \\
\text { apa yang mereka ingin mengambil } \\
\text { tindakan konselor. Prediksi dengan } \\
\text { direktif adalah bahwa konseli akan } \\
\text { melakukan apa yang disarankan. }\end{array}$ \\
\hline Nasehat/informasi & $\begin{array}{l}\text { Menyediakan saran, ide-ide } \\
\text { pembelajaran, PR, nasehat bagaimana } \\
\text { harus bertindak, berpikir, atau } \\
\text { berperilaku. }\end{array}$ & $\begin{array}{l}\text { Dapat menyediakan konseli dengan } \\
\text { informasi baru dan berguna. } \\
\text { Informasi karir khusus adalah } \\
\text { contoh penggunaan kompetensi } \\
\text { yang diperlukan. }\end{array}$ \\
\hline $\begin{array}{l}\text { Pengungkapan } \\
\text { (Self-Disclosure) }\end{array}$ & $\begin{array}{l}\text { Konselor berbagi pengalaman pribadi } \\
\text { dari masa lalu atau mungkin hadir } \\
\text { untuk berbagi reaksi dari konseli. }\end{array}$ & $\begin{array}{l}\text { Konselor menekankan pernyataan } \\
\text { "Saya". Keterampilan ini } \\
\text { berhubungan erat dengan umpan } \\
\text { balik dan untuk membangun } \\
\text { kepercayaan dan keterbukaan, yang } \\
\text { mengarah ke hubungan yang lebih } \\
\text { saling menguntungkan dengan } \\
\text { konseli. }\end{array}$ \\
\hline $\begin{array}{l}\text { Umpan } \\
\text { (Feedback) }\end{array}$ & $\begin{array}{l}\text { Menyediakan konseli dengan data } \\
\text { spesifik tentang bagaimana mereka } \\
\text { dilihat oleh konselor atau oleh orang } \\
\text { lain. }\end{array}$ & $\begin{array}{l}\text { Memberikan data konkret yang } \\
\text { dapat membantu konseli menyadari } \\
\text { bagaimana orang lain melihat pola } \\
\text { perilaku dan berpikir, sehingga } \\
\text { memungkinkan persepsi diri } \\
\text { terhadap berbagai alternatif. }\end{array}$ \\
\hline Konsekuensi Logis & $\begin{array}{l}\text { Konselor menjelaskan kepada konseli } \\
\text { hasil dari pemikiran yang logis. }\end{array}$ & $\begin{array}{l}\text { Menyediakan kerangka acuan } \\
\text { alternatif untuk konseli. } \\
\text { Keterampilan ini membantu konseli } \\
\text { mengantisipasi konsekuensi atau } \\
\text { hasil dari tindakan mereka. }\end{array}$ \\
\hline $\begin{array}{l}\text { Kesimpulan } \\
\text { Influencing }\end{array}$ & $\begin{array}{l}\text { Sering digunakan di dalam atau di } \\
\text { dekat akhir sesi untuk merangkum } \\
\text { komentar-komentar dari konselor; } \\
\text { paling sering digunakan dalam } \\
\text { kombinasi dengan kesimpulan. }\end{array}$ & $\begin{array}{l}\text { Konselor merangkum apa yang } \\
\text { telah terjadi di intervieu. } \\
\text { Keterampilan ini dirancang untuk } \\
\text { membantu generalisasi dari } \\
\text { intervieu untuk kehidupan sehari- } \\
\text { hari. }\end{array}$ \\
\hline
\end{tabular}

Orientasi teoritis memainkan peran penting dalam penggunaan interpretasi, serta keterampilan yang paling berpengaruh (lihat tabel 1.2).

Tabel 1.2 Microskill/Keterampilan yang Berbeda Pola untuk Teori Berbeda

\begin{tabular}{l|l|l|l}
\hline $\begin{array}{l}\text { Kategori } \\
\text { Microskill }\end{array}$ & Client-Centered Theory & Psyhodynamic Theory & Multicultural Theory \\
\hline
\end{tabular}


Jurnal Konseling dan Pendidikan

\begin{tabular}{|c|c|c|c|}
\hline Focus & $\begin{array}{l}\text { Terutama pada konseli } \\
\text { individu. Masalahnya } \\
\text { akan sering } \\
\text { dikonseptualisasikan } \\
\text { sebagai kebutuhan sendiri } \\
\text { yang unik dan keinginan. } \\
\text { Tujuan utamanya adalah } \\
\text { aktualisasi diri }\end{array}$ & $\begin{array}{l}\text { Terutama pada konseli } \\
\text { individu. Masalahnya } \\
\text { adalah untuk memahami } \\
\text { bagaimana pengaruh } \\
\text { pengalaman masa lalu } \\
\text { mempengaruhi apa yang } \\
\text { terjadi di masa sekarang. } \\
\text { Tujuan utamanya adalah } \\
\text { untuk memahami fungsi } \\
\text { mental bawah sadar. }\end{array}$ & $\begin{array}{l}\text { Keseimbangan antara individu, } \\
\text { keluarga dan isu-isu } \\
\text { multikultural. Masalahnya } \\
\text { dianggap dikembangkan dalam } \\
\text { suatu konteks. Tujuan utama } \\
\text { adalah untuk memahami fungsi } \\
\text { mental. Tujuan penting adalah } \\
\text { untuk membantu konseli } \\
\text { memahami diri dalam kaitannya } \\
\text { dengan konteks dan mengambil } \\
\text { tindakan untuk dirinya dan } \\
\text { orang lain. }\end{array}$ \\
\hline
\end{tabular}

\begin{tabular}{|c|c|c|c|}
\hline $\begin{array}{l}\text { Listening } \\
\text { Skills }\end{array}$ & 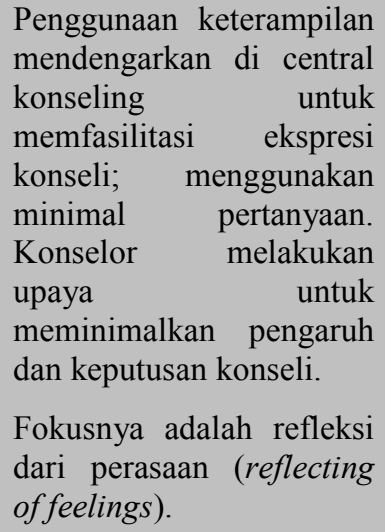 & $\begin{array}{lr}\text { Dasar mendengarkan } \\
\text { secara berurutan } \\
\text { digunakan untuk } \\
\text { menggambar data pada } \\
\text { teori psikodinamik. Dan } \\
\text { pertanyaan menantang } \\
\text { sangat penting untuk } \\
\text { memfasilitasi proses } \\
\text { eksplorasi r yang } \\
\text { dilakukan secara sadar. }\end{array}$ & $\begin{array}{l}\text { Dasar urutan dalam } \\
\text { mendengarkan yang digunakan } \\
\text { untuk memudahkan pemahaman } \\
\text { diri konseli dari sistem. } \\
\text { Konselor akan cenderung untuk } \\
\text { mendengarkan masalah-masalah } \\
\text { keluarga dan kontekstual yang } \\
\text { mempengaruhi ekspresi konseli } \\
\text { itu sendiri. }\end{array}$ \\
\hline $\begin{array}{l}\text { Influencing } \\
\text { Skills }\end{array}$ & $\begin{array}{l}\text { Umpan balik dan refleksi } \\
\text { makna yang paling umum } \\
\text { digunakan. } \\
\text { Interpretasi dan } \\
\text { pengulangan pemikiran } \\
\text { dihindari. Ada sedikit } \\
\text { upaya atau tidak untuk } \\
\text { mengarahkan konseli } \\
\text { dalam berperilaku. }\end{array}$ & $\begin{array}{l}\text { Interpretasi adalah inti } \\
\text { dari keterampilan. Pada } \\
\text { tahap akhir dari proses } \\
\text { konseling, } \\
\text { Keterampilan } \\
\text { interpretasi/ pemikiran } \\
\text { ulang mungkin hanya } \\
\text { digunakan. Ada sedikit } \\
\text { atau tidaknya upaya } \\
\text { untuk membawa konseli } \\
\text { dalam berperilaku. }\end{array}$ & $\begin{array}{l}\text { Menggunakan keterampilan } \\
\text { yang berbeda sesuai dengan } \\
\text { pengaruh budaya konseli. } \\
\text { Secara umum, ada penekanan } \\
\text { lebih besar pada umpan balik } \\
\text { dan keterbukaan diri untuk } \\
\text { membangun hubungan yang } \\
\text { lebih egaliter. Menyajikan } \\
\text { kembali isu-isu budaya dan } \\
\text { keluarga. Mungkin ada upaya } \\
\text { untuk merangsang konseli untuk } \\
\text { bertindak atas isu-isu, dan juga } \\
\text { untuk meninjau tindakan konseli } \\
\text { dalam komunitas dan } \\
\text { masyarakat. }\end{array}$ \\
\hline
\end{tabular}

(Ivey, 1993)

\section{Fokus Analisis dan Perhatian Selektif}

Pada awal proses konseling konselor sering fokus pada masalah, bukan orang-orang di depan mereka. Hal ini umumnya (tetapi tidak selalu) lebih bijaksana untuk fokus pertama pada konseli dan kemudian pada masalah. Hal ini menggoda untuk fokus pada masalah dan mengatasinya, bahkan mungkin mengabaikan pikiran dan perasaan konseli dalam proses. 
Jurnal Konseling dan Pendidikan

Dengan fokus pada konseli, konselor menunjukkan minat pada orang-orang ini dan apa yang orang rasakan dan pikirkan. Konseling adalah untuk konseli, dan setelah itu untuk semuanya. Walaupun fokusnya biasanya berada di konseli, itu bisa sangat berharga untuk memperluas fokus secara seimbang untuk mencakup beberapa dimensi tambahan.

Analisis tujuh dimensi dari microskill berikut ini penting untuk memahami apa yang terjadi dalam setiap sesi terapi. Konselor dapat merespon pernyataan dari konseli menurut Ivey (1993) dalam beberapa cara: (1) fokus konseli, (2) pendekatan yang lain, (3) fokus pada keluarga , (4) fokus pada masalah, (5) masalah/fokus utama pada kolseli, (6) fokus pada pendekatan, dan (7) Budaya/lingkungan/kontekstual.

Fokus analisis adalah berkaitan dengan subjek atau tema utama dari konseli-konselor. Sekali lagi harus ditekankan bahwa jenis-jenis fokus intervieu tetap sesuai pada saat itu, dan pada kenyataannya, harus disertakan jika konseling harus relevan dengan pengalaman hidup.

\section{Konfrontasi}

Kita sering menganggap konfrontasi sebagai tindakan bermusuhan dan agresif. Dalam konseling dan terapi, konfrontasi biasanya merupakan proses yang lebih lembut di mana kita menunjukkan kepada konseli perbedaan antara atau di antara sikap, pikiran, atau perilaku. Dalam konfrontasi, individu langsung dihadapkan dengan fakta bahwa selain mungkin mengatakan apa yang mereka maksudkan, atau melakukan selain dari apa yang mereka katakan.

Konfrontasi merupakan teknik yang menantang konseli untuk melihat adanya inkonsistensi antara perkataan dengan perbuatan atau bahasa badan, ide awal dengan ide berikutnya, senyum dengan kepedihan, dan sebagainya. Tujuannya adalah : (1) mendorong klien mengadakan penelitian diri secara jujur; (2) meningkatkan potensi klien; (3) membawa klien kepada kesadaran adanya diskrepansi; konflik, atau kontradiksi dalam dirinya.

Penggunaan teknik ini hendaknya dilakukan secara hati-hati, yaitu dengan : (1) memberi komentar khusus terhadap klien yang tidak konsisten dengan cara dan waktu yang tepat; (2) tidak menilai apalagi menyalahkan; (3) dilakukan dengan perilaku attending dan empati.

\section{Domain Konseling Multikultural}

McFadden (1996: 233-234) menyatakan pentingnya menjadi kompeten dalam budaya:

Bagi konselor untuk merespon kebutuhan para pelanggan yang multi budaya, mereka harus bisa bekerja secara efektif dengan orang dari berbagai latar belakang yang berbeda dalam sebuah cara yang setaraf dengan menghormati budaya konseli tersebut.

Namun dalam bahasan lainnya, lihatlah bagaimana Petterson (1996: 236) membandingkan dua sudut pandangan, yaitu:

Ada tiga kesalahan serius yang dapat dibuat dalam konseling multikultural. Kesalahan pertama adalah penekanan yang berlebihan pada kesamaan, yang membawa pada sebuah titik leleh dimana mayoritas menjadi pemenang melawan minoritas, menyepelekan identitas budaya. Kesalahan kedua adalah penekanan yang berlebihan pada perbedaan, yang membawa pada penggolongan dan keterlepasan ikatan. Mengacuhkan perlunya pekerjaan berat yang anggap biasa, kesalahan ketiga adalah menganggap bahwa seseorang harus menekankan baik kesamaan maupun perbedaan. [ini adalah] ... sebuah dikotomi yang salah.

Tanggapan Petterson kurang lebih menggambarkan keadaan dimana kita sekarang ini. Meskipun ada kesinambungan yang harus dihormati karena banyaknya aplikasi dari mikroskill dan teknik konseling berbasis "percobaan dan kebenaran" pada masa lalu, sekarang ada sebuah penekanan pada pemahaman identitas budaya konseli kita, dan dapat menggunakan keahlian secara tepat yang akan memfasilitasi perkembangan konseli secara maksimal. 
Jurnal Konseling dan Pendidikan

Oleh karena itu, mengutip pernyataan dari Axelson (1999:22), kita akan melihat konseling multikultural dalam konteks berikut:

Konseling Multikultural meliputi semua komponen dari banyak lingkungan budaya yang berbeda-beda dalam sebuah masyarakat yang demokratis, bersama dengan teori-teori, teknik, dan latihan konseling yang bersangkutan. Dalam hal ini, pendekatan dimasukan kedalam pertimbangan khusus latar belakang tradisional dan masa sekarang dan pengalaman lingkungan dari konseli yang berbeda beda dan betapa kebutuhan mungkin diidentifikasi dan dipenuhi melalui sumber-sumber yang membantu profesi.

\section{Kompetensi Konselor Multikutural}

Kompetensi ini, yang mewakili standar minimal yang diperlukan konselor jika mereka akan bekerja secara efektif dengan konseli yang berbeda-beda, menggambarkan sikap dan keyakinan, pengetahuan, dan keahlian dalam tiga area: (1) kesadaran diri konselor terhadap anggapan, nilai-nilai, dan prasangka-prasangka, (2) pengetahuan konselor tentang pandangan dunia konseli yang berbeda budaya, dan (3) keterbiasaan dengan strategi intervensi dan tekniknya.

\section{Domain Kompetensi Konselor Multikultural}

Arredondo, dkk (1996) menyatakan bahwa kompetensi konselor multikultural, terdiri dari: (1) keyakinan dan sikap (beliefs and attitude), (2) pengetahuan (knowledge), dan (3) keterampilan (skill).

Senada dengan hal tersebut di atas menurut Corey (2005:24) bahwa dalam konseling multikultural memiliki tiga domain kompetensi, yaitu : (1) Keyakinan dan sikap, (2) Pengetahuan, dan (3) Keterampilan dan strategi intervensi. Keyakinan dan sikap konselor menyangkut persoalan bias personal, nilai-nilai dan masalah yang akan dihadapi serta kemampuan bekerja dalam perbedaan budaya, sedangkan faktor pengetahuan menyangkut kemampuan membangun komunikasi personal secara profesional untuk memberikan layanan kepada konseli dengan pemahaman latar belakang budaya yang beragam. Kompetensi yang tidak kalah pentingnya adalah ketrampilan memakai metode dan strategi dalam menjelaskan tujuan konseling secara konsisten dalam latar perspektif budaya yang bervariatif.

Cross cultural memiliki makna sebagai sebuah studi dari berbagai budaya. Baik psikologi, sosiologi maupun konseling tidak dapat dipisahkan dari perspektif budaya, karena aspek perilaku yang berada dalam budaya tertentu tidak sama dengan budaya internal. Segal (1990) mendeskripsikan beberapa hal yang penting diperhatikan dalam memahami perspektif budaya adalah : Pertama, adanya tingkah laku manusia yang dipandang konselor dalam konteks sosial budaya di mana tingkah laku terjadi. Konsep ini menggambarkan bahwa bagaimanapunjuga frame work terhadap individu tidak dapat dipisahkan oleh pola kebiasaan dari mana individu berasal, sehingga esensi latar belakang budaya konseli menjadi instrumen penting untuk memahami dan memaknai apalagi memberikan layanan-Iayanan bantuan kepada individu. Kedua, budaya memiliki pengaruh pada kognisi dalam belajar. Ketiga, ada keeratan hubungan antara kepribadian dengan perilaku sosial. Kepribadian individu dapat dipkonselorng melaui gambaran perilaku kultural individu, perilaku tertentu akan berdampak pada kepribadian yang terbentuk dari kebiasaan perilaku yang ditunjukkan oleh latar belakang kultural. Keempat, setiap budaya senantiasa berubah-ubah, salah satu faktor pendukungnya adalah hubungan antar budaya. Persinggungan antara budaya satu dengan budaya yang lain akan ikut mewarnai pola perubahan budaya yang terjadi dalam budaya tertentu. Perkembangan ilmu konseling yang selama ini berorientasi pada budaya barat sedikit banyak mempengaruhi pola hubungan antara individu yang terbentuk di budaya lokal.

\section{Menerapkan Microskills dalam Domain Mutikultural}

Inovasi terbaru adalah aplikasi microskills multikultural. Dengan tujuan untuk memberikan panduan dalam memproduksi beberapa teori yang lebih relevan dan praktek-praktek budaya. Dalam perkembangan teori adalah kesadaran bahwa teori-teori yang ditarik dari perspektif budaya. 
Jurnal Konseling dan Pendidikan

Langkah-langkah berikut ini memberikan ide-ide untuk menghasilkan teori dan praktek budaya yang relevan menurut Ivey (1993), yaitu:

1. Perhatikan budaya itu sendiri. Apa karakteristik pribadi dan keterampilan interpersonal penting dalam budaya ini? Tujuan ini meliputi penelitian lapangan, intervieu dengan informan kunci dan membaca kerangka antropologi.

2. Mengidentifikasi keterampilan khusus dan strategi yang dapat digunakan dalam membantu hubungan modern. Mengatur pola dalam strategi dan menguji mereka dalam praktek konseling. Kikoski (1980) juga menemukan bahwa perhatian yang besar bersama dan bimbingan ke arah pendekatan direktif lebih untuk membantu.

3. Menguji teori baru telah membantu dan keterampilan dalam tindakan.

Bagi konseli yang berbeda secara budaya menurut Quintana \& Bernal (1995), konselor diharapkan memiliki kemampuan secara profesional dalam menghasilkan: (1) konselor mempunyai sebuah pemahaman yang lebih baik mengenai keberagaman, (2) konselor menjadi bisa membuat diagnosa yang lebih akurat, (3) sebuah penurunan dalam angka drop out dari konseling, dan (4) sebuah peningkatan dalam kepuasan terhadap proses konseling.

Adapun menurut Arrendondo, dkk (1996) domain kompetensi konseling multikultural untuk pendidikan dan praktek, antara lain:

1. Kesadaran konselor tentang nilai-nilai budaya sendiri dan bias (Counselor Awareness of Own Cultural Values and Biases), yaitu:

- Sikap dan Keyakinan (Attitudes and Beliefs)

- Pengetahuan (Knowledge)

- Keterampilan (Skills)

2. Kesadaran konselor akan cara pandang konseli (Counselor Awareness of Client' Worldview)

- Sikap dan Keyakinan (Attitudes and Beliefs)

- Pengetahuan (Knowledge)

3. Strategi intervensi budaya yang tepat (Culturally Intervention Strategies)

- Sikap dan Keyakinan (Attitudes and Beliefs)

- Pengetahuan (Knowledge)

Counselor Awareness memiliki kemampuan dalam mengembangkan profesi yang terkait dengan dimensi sosial dan tanggungjawab terhhn adap masyarakat. Konselor memiliki kemampuan penerimaan secara emosional kepada konselinya, dan konselor mempunyai self awareness terhadap potensi dan kemampuan dirinya.

\section{Keterbatasan dan Implikasi dari Pendekatan Microskills}

Microskills mencatat gambaran yang jelas tentang perilaku. Meskipun model awal tidak mengambil isuisu budaya, pendekatan keakuratan yang menyebabkan saat ini, presentasi budaya diharapkan akan lebih sensitif. Sekarang aksioma pendekatan microskills bahwa semua intervieu harus memperhitungkan perbedaan individu dan multikultural.

\section{KESIMPULAN}

Microcounseling selama bertahun-tahun terus-menerus menekankan fokus keseimbangan antara masalah pribadi dan kontekstual, terutama budaya dan lingkungan. Microcounseling (Ivey, 1971; Ivey \& Ivey 
Jurnal Konseling dan Pendidikan

2003) menekankan pentingnya konsep fokus dalam intervieu. Jika konselor berfokus pada konseli dan masalah konseli, konseli konstruksi dari masalah ini biasanya dalam hal individualistis dengan atribusi permasalahan terfokus pada individu, dan dia atau tanggung jawabnya untuk perubahan pribadi.

Ogbonnaya (1994) telah selangkah lebih maju ketika ia berbicara tentang orang dalam masyarakat dengan banyak implikasi dari pandangan kontekstual yang luas. Pandangan ini, tentu saja, dapat dibandingkan dengan teori orientasi individualistik dan strategi yang lebih humanistik, kognitif-perilaku dan psikodinamik.

Pendekatan microskill dapat digunakan dalam mengidentifikasi faktor-faktor dari respon nonverbal untuk diri konselor sendiri dan konseli. Konselor di dalam proses intervieu menggunakan mikroskills dalam proses menerima (attending), mendengarkan (listening), dan mempengaruhi (influencing), serta dampak potensial pada konseli untuk berubah. Begitu pula ketika menggunakan konfrontasi mikroskill, dan keterampilan intervieu sebagai acuan frame multicultural.

\section{DAFTAR PUSTAKA}

Arredondo, P.,et.al,. (1996). Operationalization of the Multicultural Counseling Competencies. Alexandria: AMCD. Virginia.

Asosiasi Bimbingan dan Konseling Indonesia. "Kode Etik Konselor Indonesia”

Corey, Gerald. (2005). Theory and Practice of Counseling and Psychotherapy. Seventh Edition. Belmont: Brooks/ColeThompson Learning.

Cornish, Jennifer A. Erickson., et.al,. (2010). Handbook of Multicultural Counseling Competencies. New Jersey: John Wiley \& Sons, Inc.

D’Andrea, M., \& Daniels, J. (2001). RESPECTFUL counseling:Anintegrative model for counselors. In D. PopeDavis \& H. Coleman (Eds.), The interface of class, culture and gender in counseling (pp.417-466). Thousand Oaks, CA: Sage.

Ivey, A.E. dan Ivey, MB. (2003). Intentional Interviewing and Counseling. Singapore: Thomson Brooks Cole.

Ivey, A.E., Ivey, MB., dan Morgan, Lynn Simek (1993). Counseling and Psychotherapy: a Multicultural Perspective. Singapore: Allyn and Bacon.

Ivey, A.E. (1988a). Intentional interviewing and Counseling. Pacific Grove, CA: Brooks/Cole.

Ivey, A.E. (1973). Microcounseling: Innovations in Interviewing Training. Springfield, IL: Thomas.

Sue, D.W \& David Sue. (2003). Counseling the Culturally Diverse: Theory and Practice ( ${ }^{\text {th }}$ Edition). USA: John Wiley \& Sons, Inc.

Sue, et.al. (1992). Multicultural Counseling Competencies \& Stkonselorrds: A Call to the Profession. Journal of Counseling and Development. Marc/April 1992. Vol. 70.

Sue. D.W. (1990). Culture-specific strategies in counseling: A conceptual framework. Professional Psychology, 21, 424-33.

Surya, Mohamad. (2003). Psikologi Konseling. Bandung: Pustaka Bani Quraisy.

Patterson, C. H. (2004). Do we need multicultural counseling competencies. Journal of Mental Health Counseling, Volum 26, Number 1, January 2004. Pages 67-73.

Perry, C. Wayne. (2002). Basic Counseling Techniques (a beginning therapist's toolkit). USA: Thomson Brooks Cole 